\title{
Chinese Tertiary Accounting Student's Perceptions of Certified Public Accountants and Their Career Job Choice
}

\author{
Jerry Collins Boateng \\ Hangzhou Dianzi University, School of International Education, Department of Accounting \\ Hangzhou, Xiasha, Xuelin Street, Zhejiang Province, P. R. China
}

\begin{abstract}
The main purpose of the study was to examine Chinese Tertiary Accounting student's perception of Certified Public Accountants and the extent to which the perception influences their career job choice between public and private accounting sectors. In respect of this, the study sort to achieve the following aims;

- What are accounting tertiary student's perceptions of the certified public accountant?

- What are the perception differences between male and female tertiary accounting students about CICPA?

- Which accounting job sector is likely to be chosen by accounting tertiary students after graduation?

The study used a sample of 135 undergraduate and graduate students (graduate students were those preparing to write CPA exams) from Hangzhou Dianzi University. Questionnaire consisting of 27 items were used which employed the Likert scale ranging from strongly disagree to strongly agree. These were completed at the end of the second semester in 2018. Data collected was entered and analysed using SPSS version 20. The data was analysed using descriptive and inferential statistics. Specifically, a multiple regression was conducted to determine the effect of accountant's negative attitude, accounting job requirements, image of the accounting profession, and accounting job outcomes on student's choice of public accounting job or job intentions. On the images of the accounting profession, the study found that accounting was rated higher by the respondent with regard to accounting job being dull, routine and monotonous. The findings of the study also indicated that individual's choice of career is determined by the perceived outcomes (benefits) of the job. Again, in relation to job choice as to whether to work in the public or private accounting sector majority of the respondent selected private accounting sector over public accounting sector. Hence, Policy makers must help make the public accounting sector more attractive by educating students on the importance of being a public servant. Despite the limitations of the study It would still be helpful to Policy makers to make new and modify their strategies in light of the issues identified.
\end{abstract}

Keywords: Tertiary Accounting Students, Perception, Certified Public Accountant, Career Job Intentions.

DOI: $10.7176 / \mathrm{RJFA} / 10-16-02$

Publication date: August $31^{\text {st }} 2019$

\section{Introduction}

Accounting is one of the most popular professions in the world. The importance of this profession cannot be undermined. Accounting started when the only system of trade in the world was barter trade, where people recorded their transactions in simple ledgers which showed the time of trade and the commodity that was traded. But today, accounting has undergone massive changes over the last decades, particularly with the advance in technology. It is fair to say that there is no business in this modern world without accounting or accountant. Despite its popularity, there are certain negative connotations that have evolved in the past decades which need to be addressed in order to improve the image the profession. People have over the years had negative perception over the accounting profession and this is gradually reducing the image and the integrity of the profession. As a result of this, the study seeks to provide useful information that will help eradicate the problems that Certified Public Accountants face as a result of the perceptions that people have over the profession and also help accounting students or those willing to 'change gears' in their career in making career choice and job decision. A great number of prior researches focused on the career choice of accounting as major course (Cory, 1992; Cohen \& Hanno, 1993; Fisher \& Murphy, 1995; Friedlan, 1995; Saudagaran, 1996; Mladenovic, 2000, Tourna et al., 2009, Saeman, \& Crooker 1999, Coate et al., 2003, Byrne \& Willis 2005), but little attention has been given to the area of student's accounting job decisions. Simply put, which accounting career path do students want to pursue? Identifying a clear job decision in accounting is problematic because accounting has several career job options such as Public Accounting Jobs (Forensic Accountant, Real Estate Appraiser, Tax Accountant, Tax Attorney, and Tax Preparer), Private Accounting Jobs (Account Clerk, Accounts Payable and Receivable Clerk, Accounting Information System Specialist, Actuarial Accountant or Insurance Accountant, Bookkeeping, Budget Analyst, Capital Accountant, Comptroller or Financial Controller, Cost Accountant, Environmental Accountant or Sustainability Measurement, and Payroll Accountant, Business Valuation Specialist, Certified Financial Planner, Financial Analyst, and Tax Consultant).

Despite teaching accounting in the university, there are many areas or ways in which it can be practicalised. An accountant may even choose to be self- employed. Arthur, Hall and Lawrence (1989) as cited in Arthur, Khapova \& Wilderom (2005) stated that a career is the unfolding sequence of a person's work experiences over a 
period of time. A career is not static but unfolds over a period of time. The Business Dictionary (2014) defines a career as the progress and actions taken by a person throughout a lifetime, especially those related to that person's occupations. It is made up of the jobs held, titles earned and work accomplished over a long period of time rather than just referring to one position.

The initial picture that might come to your mind when they think of accountants is that, an accountant cheats, steals, or is a tyrant relaxingly waiting to take disturbed souls into a jobless despair. The problem is not about getting job but being able to practicalised the knowledge acquired in the accounting field. Most graduates will always want to have the 'already made jobs' but do not want to use their technical skills acquired from the study of accounting. This means that there is a gap between accounting knowledge acquired and the use of the accounting knowledge acquired. The accounting profession has in time past, received several negative attributes (dull, indifferent, fraud, conservative, non-creative, boring, exploitations in various forms, corruptions, bribery and corruptions, just to name but a few) from both the public and its stakeholders. Some of these negative attributes still persist in today's accounting profession. These negative practices emanated from bad accounting dealings involving the accountant wishing to satisfy his or her selfish desires and creating an environment to induce its stakeholders. Moreover, images such as accounting being mechanical, repetitive, number crunching, introverted, methodical and tedious are common (Cory, 1992; Cohen \& Hanno, 1993; Fisher \& Murphy, 1995; Friedlan, 1995; Saudagaran, 1996; Mladenovic, 2000) A typical example of these inappropriate accounting dealings can be inferred from Enron Corporations, a US large corporation and WorldCom Incorporation, a large US Telecommunications carrier, their bad dealings were partly associated with the accounting profession being unregulated in the 1990s. Satoshi, S. \& Gregory, B. (2006) noted that, the negative practices created various implications that need to be addressed in order to reverse the current situation of the problematic unpopularity towards the accounting sector. Several researchers have focused on the perception of the accounting profession, but in fact, mostly on the positive aspect thereby neglecting the negative perception that can ultimately ruins the career of the accounting profession. Accounting students are motivated to pursue the accounting profession because of the positive perception that they have of it, such motivators are the different opportunities it offers and the interesting nature of the work confirming the arguments of; Tourna et al., (2009), Saeman and Crooker (1999), Coate et al., (2003), Byrne and Willis (2005). Accounting Profession has been one of the most appealing and important fields that every individual attached integrity and respect, but in current years, enrolment in the accounting profession has been deteriorating. The accounting profession has lost its ability to attract good and top students to the field as noted by (Albrecht and Sack, 2001; Marriott \& Marriott, 2003; byrne and willis, 2005). Accounting academics have also analytically argued that the perception students' hold of the accounting profession will influence their selection of accounting as their major course. Cohen and Hanno, (1993), differences in cultural and stages of economic development affect perception that people have of the profession

Despite the numerous modifications and changes that have been done by accounting professional bodies and introduction of International Accounting Standards and International Financial Reporting Standards, there still exist these negative and inappropriate dealings. This has created serious repercussions, persistently and alarmingly reducing the image and integrity of the accounting profession. The unsavoury nature and integrity of the profession is a cause of worry and concern to many stakeholders. This has therefore created gap in the mind of researchers as little studies have been conducted empirically to investigate how the negative perceptions of accounting students affects the accountant's work with particular emphasis on the certified public accountants. The study seeks to investigate the extent to which perception of the Accounting Profession (AP) affects students' job choice as to either to take up public or private sector accounting job. It is this gap in knowledge that has necessitated this research.

Basically, the study seeks to provide empirical findings on accounting tertiary students' perceptions of CICPA and their accounting job choice in between the public accounting and private accounting jobs. The study covers the following areas; (1) investigates accounting student's perception of CICPA with respect to the following areas attribute, image, job demands and job outcomes. (2) Explore tertiary students' choice of accounting job between public and private accounting jobs after graduation.

The following research questions were used for the study;

1. What are accounting tertiary student's perceptions of the certified public accountant?

2. What are the perception differences between male and female tertiary accounting students about CICPA?

3. Which accounting job sector is likely to be chosen by accounting tertiary students after graduation?

The study will be of great importance to accounting policy makers, accounting professionals and certified public accountants, and students. The empirical evidence of the students' perceptions of the CICPA and accounting job or career choice contributing to policy making and the recommendations will provide a relevant model for educational policy makers. Policy makers such as; It will help School Guidance and Counselors to educate and guide students in the choice of accounting jobs so that students will work towards the achievement of such goal and not accepting any job that comes their way after graduation. This will give a clear career path to students to achieve perfections in the field selected. According to Warrick, Daniels and Scott (2010), understanding student 
perception of employment opportunities is important to educators and recruiters. Chen, Jones, \& Mclntyre (2005) advocated that their study has implications on the recruiters/employers of accountants, educational bodies and public interest. Demagalhaes, Wilde \& Fitzgerald (2011) stated that accounting faculty and career counsellors in understanding factors that influence career choices can help advice students on the available career opportunities in accounting. This makes the study of determinants of career choice among accounting undergraduate students an important issue that is ever necessary for the development of the accounting profession. CICPA can use that as the basis for modifying their exams structure, recruitment of accountants, conducive work design, and provision and modification of codes of professional conducts. To the accounting professionals and certified public accountants, this study will suggest the appropriate work conduct and rules and know how their attitude affects students' perceptions of the profession. It will also help to address the accountant's negative behavior in a manner that will project the profession. The findings of this study could serve as benchmark for accountant's work conduct. Finally, the study will abreast students with the various avenues in the accounting profession and how best they can contribute to the elimination of the negative stereotypes against the CPA and to make good career job choice.

Geiger, et al., (2000) asserted that the unpopularity of the accounting profession held by students is partly due to a misunderstanding of accounting and its professionals driven by adverse perceptions. Corsini, R. J., (2002) posited that the prevailing negative perceptions of accounting professionals may lead inappropriate or "wrong people" to choose accounting majors or accounting careers. Compared with these prior studies, accounting literature in China has been virtually silent on these issues.

This study aims to provide useful evidence of tertiary accounting student's perceptions of the accounting profession in China and how such perceptions influence their career or job choices. The analysis of perception and its influential factors will bring us a better understanding of how to address the issue of accounting student's job choice that is currently so topical in the Chinese accounting sector. The next section will provide a literature review in an attempt to understand the historical perspective on this global issue. Several hypotheses are developed and empirically analyzed from this review. In conclusion, this paper will describe the findings, which will draw useful implications on which an attempt to tackle the issue of accounting student's job choice in China.

The study is categorized into five sections. The first one is introduction, second part is literature review which will cover my hypothesis development; the third one also gives details about the methodologies that were employed, the fourth part of the paper also deals with results and discussions, and finally results, finding, and discussions drawn from the study.

\section{Review of Related Literature}

This chapter reviews extant literature on student's perception. It covers one theory: the Theory of Planned Behavior by Martin Fishbein together with Icek Ajzen in 1975 which came as a result of further work from the Theory of Reasoned Action. This theory underpins the study. It also covers accounting career choices, hypothesis development, and conceptual framework for this study. In addition, empirical studies on factors affecting the perception of the CPA such as negative accountant's attitude, image of the accounting profession, accounting job outcome, and accounting job requirements are also considered. These empirical results are to put this study in perspective.

\subsection{Perception:}

Perception is as the ability of an individual to sense and respond to information directly or indirectly in his or her environment, either through told stories, and personal experiences through rigorous research. People may have developed certain perceptions about a particular entity or person but this may not be displayed unless triggered by argument or an issue that revolves around what he or she had already conceived.

\subsection{Theory of Planned Behaviour}

Icek Ajzen (1985) through his article 'From intentions to actions' proposed Theory of Planned Behaviour (TPB) Basically, TPB is a further work from the Theory of Reasoned Action (TRA), engineered by Martin Fishbein together with Icek Ajzen in 1975 as stated in Fishbein and Ajzens (1975), Churchman, (2013). TRA posits that attitudes and normative factors are relative importance factors that determined different individual, situation and behavioural intention (Vallerand et al., 1991). The limitations in the original model in dealing with behaviours over which people have incomplete volitional control triggered the further works on TPB (Ajzen, 1991).

According to Ajzen (1991), TPB is widely used in several research study areas such as social psychology (Armitage and Conner, 2001) and social networking (Cameron, 2010). Krzeski (2011), focused on investigating attitudes, subjective norms and behavioural capabilities among adults' drink choices in Southwest Virginians. The subjective norm is referred to the perceived social pressure whether to perform the behavior as a sum of the perceived expectations of specific referent weighted by the individual's "motivation to comply" with those expectations (Fishbein \& Ajzen 1975). According to (Ajzen, 1991) perceived behavioural control (PBC) is defined as people's perception of the ease or difficulty of performing the behavior of interest. This is the totality of 
individual's main control beliefs, which is the specific belief and the perceived power of factor ability to aid or restrain performance of the behavior (Ajzen, 1991).

As asserted by TPB, attitude (personal beliefs) together with subjective norms (referent) and perceived behavioural control (control factors) will impacts a person's intention, and then influence their behaviour (Ajzen, 1991, 2005). A construct of TPB is attitude towards the behaviour which depicts the individual's total positive or negative evaluations of performing a particular behavior (Ajzen, 1991).

According to Steven J. C. et al., (2003) the purpose of perception is knowledge, but this knowledge acquisition serves as a primary guide to action. Research attention is currently focused not only on external perception processes, but also the process of receiving, accessing and appraising internal bodily signals. Farb N., Daubenmier J., Price C. J.; Gard T., Kerr C., Dunn B. D., Mehling W. E. (2015) noted that maintaining desired physiological status is critical for an individual's well-being and survival. Afferent sensory signals continuously interact with higher order cognitive representations of goals, history, and environment, shaping emotional experience and motivating regulatory behavior. Steven J. C. et al., (2003) further stated that, Scientists who study perception and sensation have long understood the human senses as adaptations. According to Jerome, S. B. \& Leo, P. (1949) people go through process to form opinions, when they encounter an unfamiliar target; they become open to different informational cues and want to learn more about the target. When this happens, the individual forms selective perception and finally paints a consistent picture of the target.

According to Alan Saks and Gary Johns, (2011) there are three components to perception. The person who becomes aware about something and comes to final understanding, encounters these 3 factors that can influence his or her perceptions: experience, motivational state and finally emotional, stated to be the main factors. In different motivational or emotional states, the perceiver will react to or perceive something in different ways. Also in different situations he or she might employ a "perceptual defence" Alan Saks and Gary Johns, (2011) posits again that the "perceptual defence" exist where individuals tends to "see what they want to see" another aspect is the person who is being perceived or judged. Ambiguity or lack of information about a target leads to a greater need for interpretation and addition. The Situation also greatly influences perceptions because different situations may call for additional information about the target. Berry, K.T., O'Bryan, D. \& Swanson, P.K. (2004) find that high school teachers and counselors also have distorted perceptions of the knowledge, skills, and abilities necessary for success in the accounting profession and thus many students see accounting as a necessary evil, not as an exciting career path. Educators and practitioners need to rectify misconceptions and do a better job of selling the profession's image." Albrecht, S.W. \& Sack, R. J. (2001) Cory (1992) provided examples of how accountants were portrayed in the media, arguing that these stereotypes were often used in making career decisions and negative perceptions resulted in a self-fulfilling prophecy. The accountant must know that his or her actions directly and indirectly affect the CPA of which he is a member. The consistency of actions can form an unchanging perception of a CPA which may serve as a stereotype. Obata (2006) argued that the relatively lower level of remuneration paid to CPAs in Japan was of major concern. Obata (2006) concluded that this lower economic benefit may discourage students from becoming a CPA even though sufficient job security with a governmental certified license has usually been very attractive to students.

\subsection{Accounting Career Choices}

Decision making is very crucial aspect of human life. The most challenging and problematic is one concerned with career choice. According to Nwobu, O., Faboyede, O. S., \& Oyewo, B (2015), the major decision that students have to make in tertiary institutions is career choice and this choice also cuts across a number of disciplines in business, social sciences and pure sciences. Accounting student at the final year consciously or sub-consciously makes up his/her mind on the kind of career to pursue after graduation. The accounting student has a reason for pursuing accounting as his or her future career. Prior researchers have demonstrated that these factors are either intrinsic or extrinsic. Ahmed, K., Alam, K. F., \& Alam, M. (1997) their results show that the students who intend to pursue a CPA career place significantly greater importance on financial and job-related factors and perceived benefit-cost ratio than those who choose a non-accounting career. Again, their discriminant analysis revealed that financial and job-related factors have the highest explanatory power differentiating the two groups, followed by the students' perception of benefits and costs associated with a CPA career. Three distinct areas from where accounting students make choices are to work in the industry, gain academic relevance or to diversify completely from accounting (Nwobu, O. et al., 2015). In Borchert, R., (2002) it was noted that career choice involves deciding on what aspect of a taught discipline to focus on. It is determined by how students perceive their environment, personality and opportunity. This implies that career choice decisions are determined by a number of internal and external pressures (Nwobu, O. et al., (2015). Ahmed, K. et al., (1997), in a study on the factors that influence students to pursue an accounting career choice, grouped 19 items into 5 factors: (i) intrinsic reward, (ii) good starting salaries, (iii) good long-term salaries, (iv) job availability, and (v) experience with accounting during High School, and among all the attributes considered their results show that only financial and market factors were significant, they were associated with students' decision to pursue an accounting career; those who had already 
chosen it realized that the benefits are greater than the drawbacks, while those who had not chosen it regarded the profession as boring.

One of the personal factors that influence the decision of accounting students to pursue a certain career path in accounting is personal interest. An accounting student has personal interest in a particular accounting career when he or she possesses an innate attraction for such a career path. For example, an accounting student may be drawn towards a particular accounting career for personal reasons not because there is any influence from anywhere else (Nwobu, O., et al., 2015). Several researches focused on the perception that students have over the accounting profession (Cory, 1992; Cohen \& Hanno, 1993; Fisher \& Murphy, 1995; Friedlan, 1995; Saudagaran, 1996; Mladenovic, 2000, Tourna et al., 2009, Saeman and Crooker 1999, Coate et al., 2003, Byrne \& Willis 2005, Mbawuni, J. (2015). and little research on the accounting job choice by the tertiary students. This paper is an extension of the works done by these researchers with much emphasis on the one done by Joseph, M., (2015). The purpose of this extension is to contribute to the eradication of the problems that tertiary students face after graduation with regards to their career job choice in accounting (Public or Private accounting job choice) which has been the gap left unresolved.

\subsection{Private Accounting Jobs and Public Accounting Jobs}

Accounting has several career options which creates challenging and serious problem for accounting students. The accounting students must first decide whether to work in the private or public sector and which type of accounting job to choose. The decision as to whether to select private sector accounting job or public sector accounting job is mainly influenced by several factors. These influential factors may be job security, term of service, job availability, and opportunities for training and development, high salary, flexible working environment, social life, good pension plan and among others. No matter whom you are, whether a new accounting graduate or needing to switch from one career to another career, you will likely consider the choice of private or public accounting jobs. Public accounting jobs as previously mentioned includes; Forensic Accountant, Real Estate Appraiser, Tax Accountant, Tax Attorney, and Tax Preparer. Although, systems used in government accounting are sometimes different from the accounting systems used in the private sector but the some of these jobs have the same or similar job titles. To become a public accountant, one must complete and get certification from the Chinese Institute of Certified Public Accountant which is the only professional body in charge of the Accountancy Profession in China. Warrick, Daniels \& Scott (2010) asserted that in prior research, government accounting (public sector accounting) has a lower perceived value than the practice of accounting in private accounting consultancy firms and business organizations. They also found that students prefer the practice of accounting in private accounting consultancy firms and business organizations more than working with the government. Government accounting offers opportunity for accountants to work with government organizations and corporations. Ahmed, K. et al., (1997) examined the influence of financial and job-related factors (parent, peer pressure, work experience, exposure to accounting in high school, and perceived benefit-cost ratio to being a chartered accountant) on the decision of students to choose to pursue a chartered accounting or non-accounting career. Of all the factors that were subject to testing, financial, job-related factors and students' perception of benefits and costs associated with a chartered accounting career rank highest in explaining students' career choice

\subsection{Accounting Profession: CICPA in China \\ 2.5.1 Professional Accounting Career}

Chinese accountancy profession was introduced in the early 20th century. During that time the profession was serving the booming national industry and commerce mainly. The profession played very imperative role in national economic recovery when the PRC came into existence. But in the Mid-20th century when China moved to a planned economic system the profession was suspend. The adoption of planned economic system was along with China's historical economic reform and opening up policies. The new system speeds up the Chinese accountancy profession steadily where it was recreated. In China, a professional accountant is a member of Chinese Institute of Certified Public Accountants. This institution is guided by professional codes of conduct. Certified accountant is a person professionally trained in accounting and holds a professional certificate from professional accounting bodies such as, Association of Chartered Certified Accountants (ACCA), Chartered Institute of Management Accountants (CIMA), Institute of Chartered Accountants in England and Wales (ICAEW), Chinese Institute of Certified Public Accountants (CICPA), CPA Australia, Institute of Chartered Accountants Ghana (ICAG) and others. P.W. Senarath Yapa, Zhen Ping Hao, (2007) conducted research on the trend of the CICPA and find out that, accounting professionalisation project in China has been derailed mainly due to lack of coordination among accounting educational institutions. It seems that the CICPA purposely exert control over the supply of accountants by limiting the membership only to those who complete its own examinations mainly to maintain the "local status" of its members. 


\subsection{Hypotheses Development}

For the purpose of distinguishing this research from prior studies, I classified accounting tertiary students as those students who are pursuing accounting as major. The following hypotheses are employed to give concrete support to the study;

H1. There is no significant difference in the perception of accountant's negative attitude between male and female accounting students.

H2. Image of the AP significantly influences the job intention among tertiary accounting students.

H3. There is a negative relationship between accounting tertiary students perception of accounting job outcomes and career choice.

H4. There is significant difference between accounting tertiary student's perception of accounting job demands.

H5. There is a significant difference in accounting student's job choice between private accounting job and public accounting job.

H6. Accountant's negative attitude in the Accounting Profession negatively affects Chinese tertiary student's job intentions.

Prior studies has shown that first year students (freshmen) have negative images such as accounting being mechanical, repetitive, number crunching, introverted, methodical and tedious are common(Cory, 1992; Cohen \& Hanno, 1993; Fisher \& Murphy, 1995; Friedlan, 1995; Saudagaran, 1996; Mladenovic, 2000) which are likely to affect their interest for the accounting profession (Ferreira \& Santoso, 2008; G. White \& M. White, 2003). These negative perceptions are not attributed to a single individual but may stem from different sources such as corporate scandals of global companies, accounting teachers' or lecturers' perception, understanding of the nature and challenges of the accounting profession, parental expectations and perceptions, peer influence, and critical experiences with practicing accountants.

\subsection{Conceptual Framework}

The conceptual framework is designed purposely for this study and to examine the hypothesis. The figure below contains the thematic areas of perceptions that the study sort to investigate and were examined as accounting student's perceptions of the AP. The thematic areas captured in Figure 1 are perceived negative accountant's attitudes, image of the AP, perceived demands of the accounting job, and perceived accounting job outcomes. These areas have been selected mainly because this study examines past and current perceptional factors that affect career job choice among students in either the public or the private accounting jobs, which have received relatively little research attention in the literatures, especially in China. This study also examines differences in students' perception of accounting profession between accounting males and females, and between undergraduate and graduate accounting students.

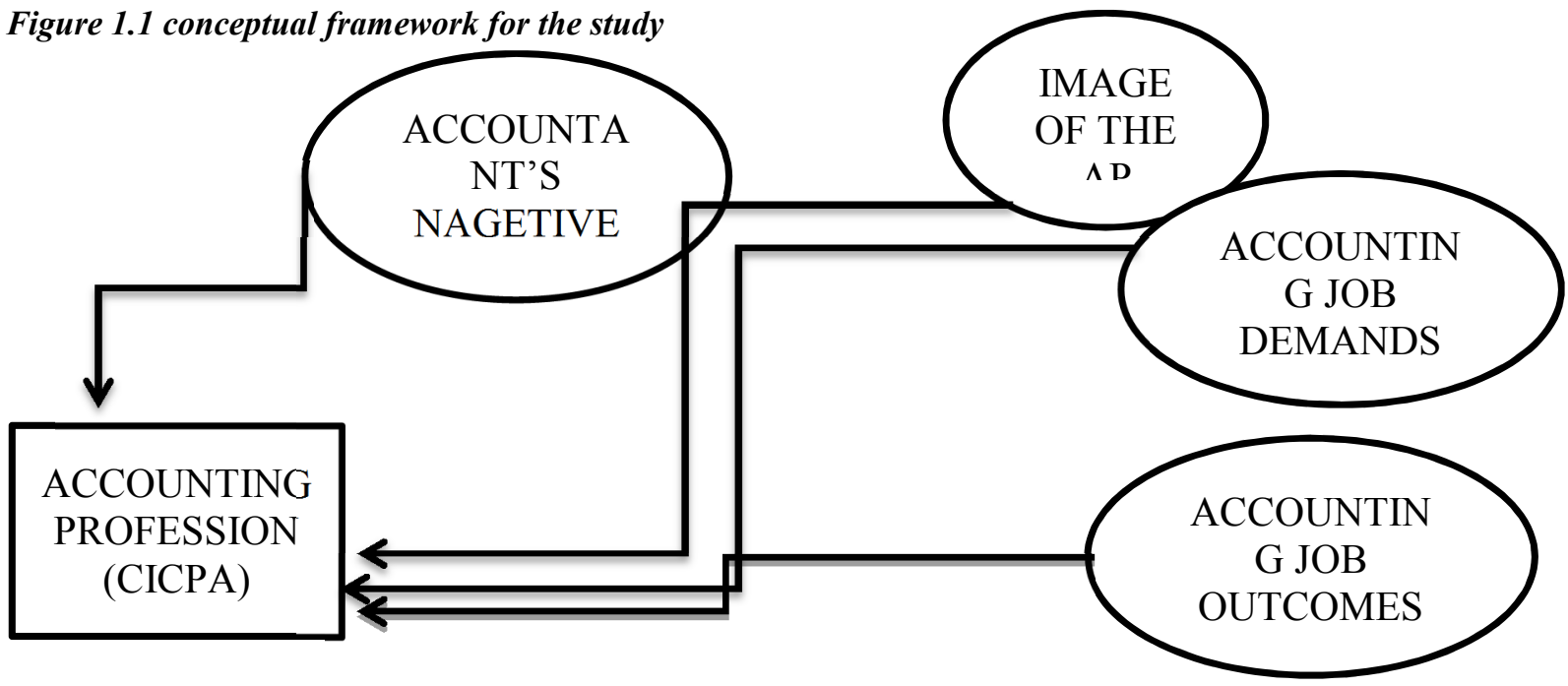

\subsection{Perceived Accountant's negative attitudes}

TRA posits that attitudes and normative factors are relative importance factors that determine different individual, situation and behavioural intention (Vallerand, R.J., Pelletier, L.G., Deshaies, P., Cuerrier, J-P., \& Mongeau, C., 1992). In general, students might have negative perception over the AP but the severity is likely to be less for the accounting students. As asserted by TPB, attitude (personal beliefs) together with subjective norms (referent) and perceived behavioural control (control factors) will impacts a person's intention then influence their behaviour (Ajzen, 1991, 2005). Cohen and Hanno (1993) studied choice of college major and found significant statistical 
differences between accounting and non-accounting majors. Non-accounting majors failed to select accounting as a major because it was 'too number-oriented' and 'boring' Cory (1992) found that, High School students appeared to have very little information concerning accounting professions. When compared to the other groups (attorneys, bankers, and marketing majors), students rated accountants as "dull", "indifferent", "conservative", and "methodical". Among these negative perceptions include the fact that AP is tagged with corruption, untruthfulness, and dishonesty, often manipulate figures in financial reports, and often do not report the true state of affairs and often hide important materials in financial reports (Wessels \& Steenkamp, 2009. Chan (2000) also noted that accountants and those charged with governance of the corporation engage in these transactions to boost earnings in order to induce or increase investors' confidence in the corporation.

\subsection{Image of the AP}

Churchman (2013) studies factors that influence students' intent to enter the accounting profession by testing accounting student's beliefs, perception, and intentions toward entering the accounting profession with TPB. Their conceptual framework sought to identify whether a difference exists between the factors that influence the career choice of high aptitude students as compared to other accounting majors. Their results indicated that attitude toward the profession (ATT), subjective norms (SN) were significant indicators of accounting majors' intent to enter the accounting profession. Students are more likely to pursue professional accountancy when they believe significant friends or family (referent) agreed to that decision. Moreover, students will tend to pursue professional accountancy if they have positive attitudes toward it. However, if students do not believe in their capability (perceived behavioural control), they will have less intention to become professional accountants (Churchman, 2013).The characteristics that the accountant exhibit either at work place or outside the work place also affects the way people think of them, a common finding across many different kinds of perception is that the perceived qualities of an object can be affected by the qualities of context (Corsini, Raymond J. 2002). Saemann and Crooker (1999) also conducted a similar study and found that traditional perceptions of accounting tend to discourage more creative students from majoring in accounting. ACCA in "Closing the Value Gap report, 2012" warned that accountants should endeavor to uphold high ethical standards in order to win public trust perceptions for the profession. This leads to the research question: how do accounting students perceive the AP?

Prior studies have found that students' perceived accountants as reputable and respected people due to the demands of the profession (Germanou, Hassall, \& Tournas, 2009; Góis \& Brás, 2013). It was revealed by Association of Chartered Certified Accountants (ACCA) report (ACCA, Closing the Value Gap, 2012), that as the role of the accountant has evolved in line with changing regulation and business law, a perception gap between the profession and the public when it comes to the issue of trust has emerged. $25 \%$ trust discrepancy was found by the report indicating the gap between how the industry perceives itself and the level of trust the public actually holds for accountants. $85 \%$ accountants agreed that accountancy as a profession should be doing more to improve its overall image.

\subsection{Demands of accounting job}

Accounting Profession like other professions also has professional rules and requirements. These rules and requirements among others include International Accounting Standards (IAS), International Financial Reporting Standards (IFRS), International Federation of Accountants (IFAC), and International Standards for Auditing (IAS), Accounting Concept and conventions and the exams requirements of the CPA. According to (Fiske \& Taylor, 2013; Meredith, Steward, \& Lewis, 2011; J. Solomon, A. Solomon, Joseph, \& Norton, 2013) accounting students may have negative perceptions about these job requirements which may not reflect the reality. This leads to the research question: how do accounting students perceive accounting job requirements? Some of the perceptions accounting job requirement include the perception that accounting job is quite challenging or demanding, requires a lot of mental energy in terms of managing complex accounting problems and conforming to accounting regulations, requires much intelligence, education and training, and is a nonstop activity that can be dull, routine and monotonous in practice (Wessels \& Steenkamp, 2009). Wrong perception about accounting job requirement can result in over ambition and unrealistic job expectations for the profession (Solomon et al., 2013).

\subsection{Perceived Accounting Job Outcomes}

Beliefs, desires, and intentions are the core concepts involved which are used to understand why someone acts in a certain way or to predict how someone will act (Kloo D., Perner, J., \& Gritzer, T. 2010). Decision making is very essential in everyday life. Accounting students might have thought of the opportunities and benefits of the accounting profession before deciding to pursue accounting. Saemann. et al., (1999) employed additional t-test analysis which revealed that students who were interested in an accounting career didn't care about the typical image of the profession, but tended to be less creative people. Despite the negative perceptions people hold over AP, accounting students may either have positive or negative perception of the AP. Prior research shows that individuals' choice of careers is determined by the perceived outcomes (benefits) of the job (Karakaya, Quigley, 
\& Bingham, 2011). The research question is: how do accounting students perceive accounting job outcomes? And some of these positive perceptions include incomes such as salaries, allowances, bonuses and other financial incentives, and opportunity for other materials possessions. And other job outcomes may be intrinsic motivation such as opportunities for career advancement, personal fulfillment, recognition and prestige, among others (Mbawuni, J., 2015). Negative or positive perceptions about job outcomes can affect accounting students' intentions (Chia et al., 2008; Dalci et al., 2013; Karakaya et al., 2011), and of joining the profession or being committed to the rigour and demands of the education and training leading to certification in the profession.

\section{Research Methodology}

This chapter describes the type of research design that was used and why it was adopted. It also describes the population, the sample and sampling technique, the research instrument that was used, and the data collection procedure. Finally, it describes the data analysis procedure that was employed to answer the research questions.

\subsection{Data Collection}

The study intends to investigate perceptions of the CPA held by tertiary accounting students studying Hangzhou Dianzi University in China. This study also explores how these perceptions may affect their job choice as either working in public and private accounting jobs. The data used in this study was collected using questionnaire completed by undergraduate and graduate Chinese students who were studying at Hangzhou Dianzi University in China. The target population was limited to only Chinese accounting students. The modes of language used in the questionnaire administration were both English and Chinese. The university has been among the best three schools in Zhejiang Province. The university provides students with a specialized high quality accounting education. The questionnaires were administered in the classroom at the university at the end of second semester in 2018.

Samples collected from the university were matched to my research purpose according to future career aspirations. They questionnaires were basically administered to two groups of students. One group (graduate/master students) was preparing themselves for the CPA exam so they could become a CPA while the other group (undergraduate) of students was studying for bachelor's degree. The study accordingly, focused on the differences in perceptions between students who want to become a CPA (graduate students) and the other students who are yet to obtain bachelor's degree.

\subsection{Questionnaire Development}

The questionnaire was designed to initially ask students demographic questions such as their gender, age, academic qualification. The second section asked respondents to complete a 27 five-point questionnaire items to measure Chinese tertiary accounting student's perception toward the AP and their career job choice between public and private accounting jobs (see Appendix). The questionnaire items were adopted from Mbawuni, J., (2015) and were further modified to fit the research purpose. The questionnaires were administered to the target students through personal contact by the researcher. The response to the questionnaire items were a five-point Likert scale ranging from strongly disagree to strongly agree. This scale was coded 1 to 5 respectively. This instrument is known as "the PAPA" which was originally developed by Saemann \& Crooker (1999). It was designed to measure students' perceptions of the accounting profession. This same inventory measure has also been used in several other accounting studies (Mbawuni, J., 2015: Byrne \& Willis, 2005). Again, in the test of the differences in the perception between male and female accounting students, Krukal-Wallis test was used. According to Hair, et al., (2010), Krual-Wallis test must be considered most appropriate non-parametric ANOVA because it is difficult to achieve all the strict assumptions of the parametric ANOVA or the T-test, especially for all items rated or evaluated by respondents.

\section{Analysis, Discussions and findings}

This section deals with the analysis and discussion of the data collected from the field and findings from the analysis. The chapter is divided into two sections. The first section focuses on the background information of the respondents. The second section deals with the presentation and discussion of the results to address the research hypothesis that were posed to guide the study.

Data was collected with hard copy questionnaires from both undergraduate and master's students. The total number of usable questionnaires retuned was in all135. Data collected was entered and analysed using SPSS version 20. Results are explained using charts and tables. 




Figure 1: Gender of respondents

Figure 1 shows the gender of respondents that partake in the survey. Females are the largest group in the data collection with a number of 93 which corresponds to $68.9 \%$ while males are 42 which corresponds to $31.1 \%$.

\section{LEVEL OF EDUCATION}

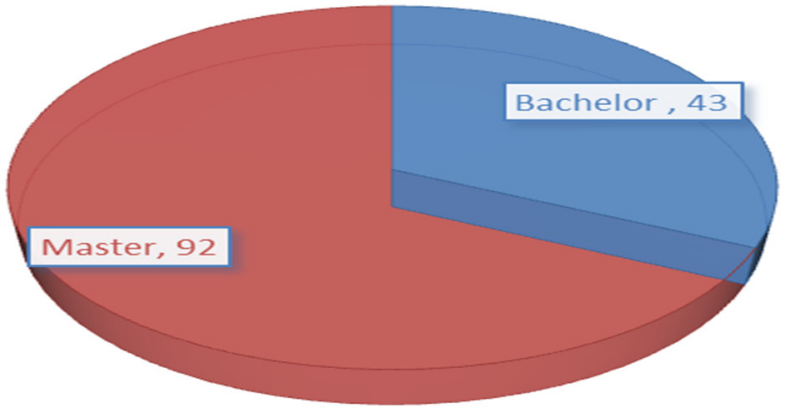

Figure 2: Age of respondents

Respondent's ages were grouped into three. Majority of the respondents fall within the ages of $20-25$, with a frequency of 82 which corresponds to $60.7 \%$, followed by $17-19$ years with a frequency of 44 which corresponds to $32.6 \%$ while the least age group is 26 - 30 years with a frequency of 9 which corresponds to $6.7 \%$

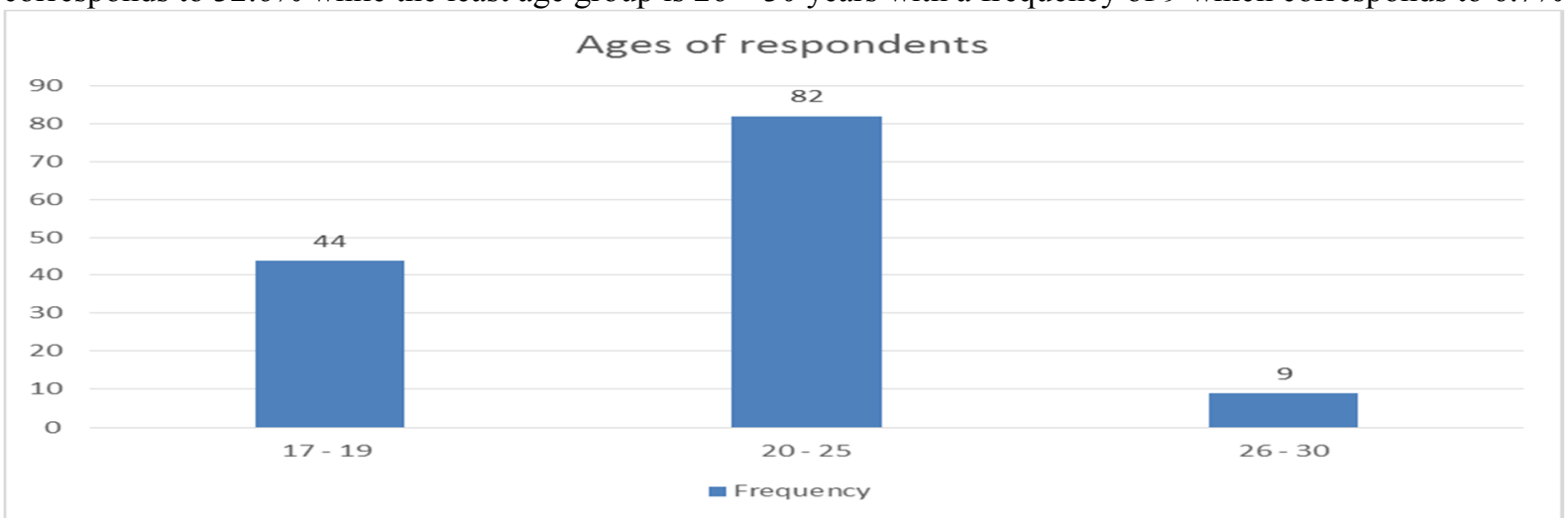

Figure 3: Level of education

From table 3, the master (Graduate) students are 92 in number which corresponds to $68.1 \%$ and bachelor degree (undergraduate) students are 43 which correspond to $31.9 \%$. The probability of choosing a student that is master's holder is 0.68 . 
Table 1: Negative Accountant's Attitudes

\begin{tabular}{|c|c|c|c|c|c|}
\hline Variables & $\begin{array}{l}\text { strongly } \\
\text { Disagree }\end{array}$ & $\begin{array}{l}\text { Disagre } \\
\mathrm{e}\end{array}$ & $\begin{array}{l}\text { Uncertai } \\
\mathrm{n}\end{array}$ & Agree & $\begin{array}{l}\text { Strongly } \\
\text { Agree }\end{array}$ \\
\hline $\begin{array}{l}\text { Manipulation of accounting } \\
\text { figures is accountant's hallmark }\end{array}$ & $21(15.6)$ & $50(37.0$ & $\begin{array}{l}28 \\
(20.7)\end{array}$ & $\begin{array}{l}31 \\
(23.0)\end{array}$ & $5(3.7)$ \\
\hline $\begin{array}{l}\text { Important information are mostly hidden } \\
\text { from users by accountant in financial } \\
\text { reports }\end{array}$ & 39 (28.9) & $\begin{array}{l}54 \\
(40.0)\end{array}$ & $\begin{array}{l}23 \\
(17.0)\end{array}$ & $\begin{array}{l}19 \\
(14.1)\end{array}$ & -- \\
\hline $\begin{array}{l}\text { Accountant makes too many } \\
\text { assumptions } \\
\text { in financial reporting which do not }\end{array}$ & $9(6.7)$ & $40(29.6$ & $\begin{array}{l}47 \\
(34.8)\end{array}$ & $\begin{array}{l}38(28.1 \\
)\end{array}$ & $1(0.7)$ \\
\hline
\end{tabular}

in financial reporting which do not

revealed the true state of affairs of

business

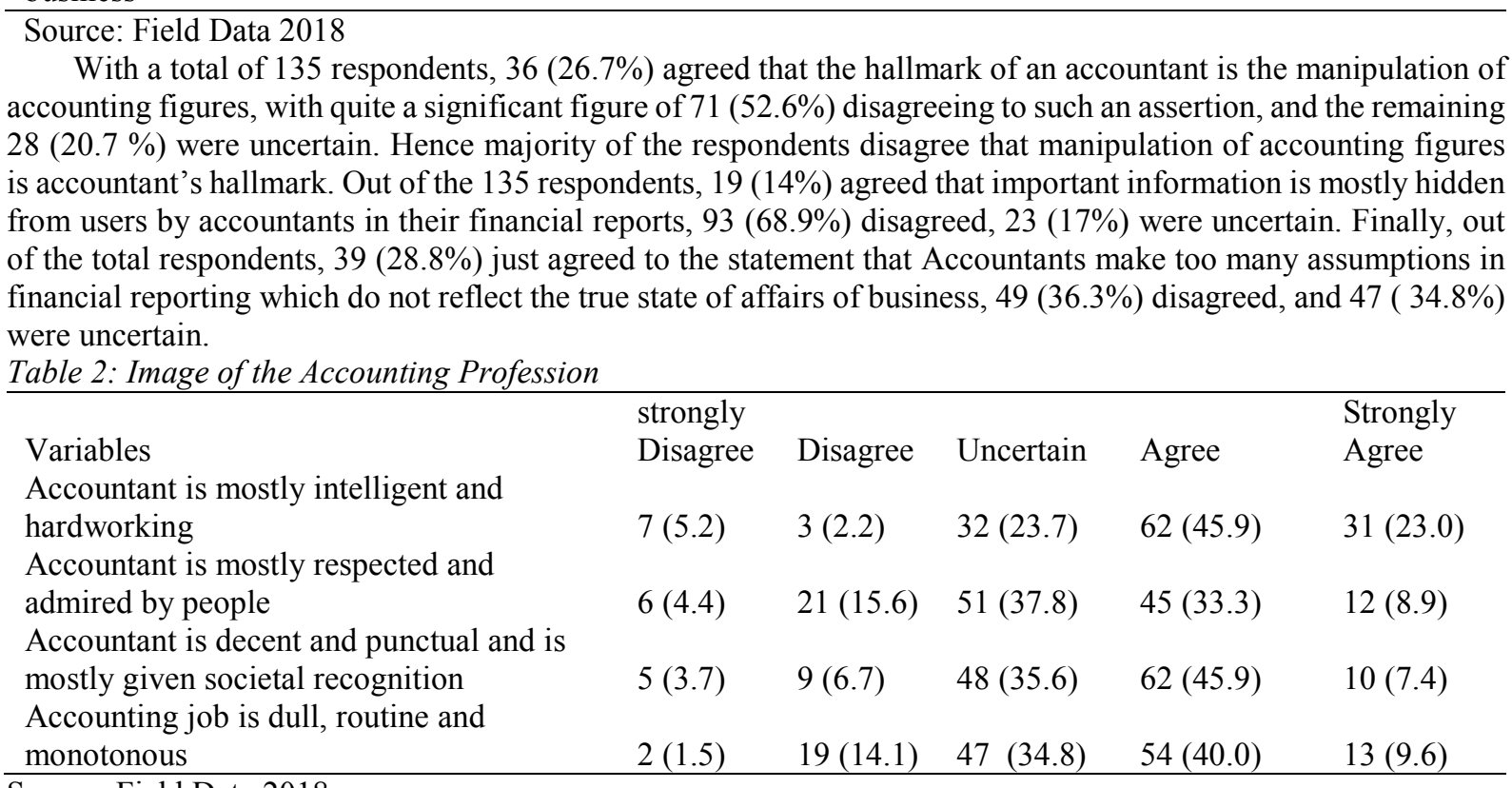

Source: Field Data 2018

Concerning the image of the Accounting profession, out of the 135 respondents, 93 (68.9\%) agreed that the profession requires some level of intelligence and hard work, $10(7.4 \%)$ disagreed, and $32(23.7 \%)$ were uncertain whether that is true or not. With the second attribute, $57(42.2 \%)$ were positive (agreed), $27(20.0 \%)$ disagreed, and $51(37.8 \%)$ were uncertain in their stance whether Accountant is mostly respected and admired by people. Also, out of the total respondents (135), 72 (53.3\%) agreed that Accountant is decent and punctual who is mostly given societal recognition, 14 (10.4\%) disagreed, 48 (35.6\%) were uncertain, and whiles 1 (.7\%) was missing. On an ending note, 67 (49.6\%) agreed that Accounting is dull, routine and monotonous job, 21 (15.6\%) disagreed, and $47(34.8 \%)$ were uncertain.

Table 3: Accounting job outcomes

\begin{tabular}{|c|c|c|c|c|c|}
\hline Variables & $\begin{array}{l}\text { strongly } \\
\text { Disagree }\end{array}$ & Disagree & Uncertain & Agree & $\begin{array}{l}\text { Strongly } \\
\text { Agree }\end{array}$ \\
\hline $\begin{array}{l}\text { Accounting job pays higher satisfactory } \\
\text { wage }\end{array}$ & $6(4.4)$ & $30(22.2)$ & $53(39.3)$ & $41(30.4)$ & $5(3.7)$ \\
\hline $\begin{array}{l}\text { Accounting job is mostly seen by people } \\
\text { as prestigious }\end{array}$ & $3(2.2)$ & $16(11.9)$ & $63(46.7)$ & $45(33.3)$ & $8(5.9)$ \\
\hline $\begin{array}{l}\text { Accounting job offers chance for training } \\
\text { and development }\end{array}$ & $3(2.2)$ & $3(2.2)$ & $23(17.0)$ & $82(60.7)$ & $24(17.8)$ \\
\hline
\end{tabular}

Source: Field Data 2018

Accounting jobs pay highly satisfactory wages was agreed by 46 (34.1\%) respondents out of the 135 respondents, $36(26.6 \%)$ disagreed, and $53(39.3 \%)$ are unsure whether that is the case or not. $53(34.2 \%)$ agreed that accounting is seen as a prestigious profession, $18(14.1 \%)$ disagreed, whiles $63(46.7 \%)$ were uncertain on how Accounting job is perceived. $106(78.5 \%)$ agreed that Accounting as a profession offer chance training and development, $6(4.4 \%)$ disagreed, and $23(17.0 \%)$ were uncertain. 
Table 4: Accounting Job Requirement

\begin{tabular}{llllll}
\hline Variables & $\begin{array}{l}\text { strongly } \\
\text { Disagree }\end{array}$ & Disagree & Uncertain & Agree & Strongly Agree \\
\hline $\begin{array}{l}\text { Accounting job requires much } \\
\text { intelligence }\end{array}$ & $5(3.7)$ & $24(17.8)$ & $50(37.0)$ & $43(31.9)$ & $13(9.6)$ \\
$\begin{array}{l}\text { Accounting job involves many rules, } \\
\text { regulations and concepts }\end{array}$ & - & $3(2.2)$ & $18(13.3)$ & $74(54.8)$ & $38(28.1)$ \\
$\begin{array}{l}\text { CICPA exams is time consuming and } \\
\text { very difficult }\end{array}$ & $4(3.0)$ & $7(5.2)$ & $33(24.4)$ & $55(40.7)$ & $36(26.7)$ \\
$\begin{array}{l}\text { CICPA exams is designed for } \\
\text { intelligent peoples }\end{array}$ & $9(6.7)$ & $34(25.2)$ & $49(36.3)$ & $32(23.7)$ & $11(8.1)$ \\
$\begin{array}{l}\text { It cost a lot of money to become a } \\
\text { CICPA }\end{array}$ & $9(6.7)$ & $29(21.5)$ & $36(26.7)$ & $42(31.1)$ & $19(14.1)$ \\
$\begin{array}{l}\text { CICPA requires high entry } \\
\text { requirements }\end{array}$ & $4(3.0)$ & $8(5.9)$ & $21(15.6)$ & $70(51.9)$ & $32(23.7)$ \\
\hline
\end{tabular}

Source: Field Data 2018

On the aspect of Accounting requirements, 56 (41.8\%) agreed that it requires much intelligence, $29(21.5 \%)$ disagreed, and $50(37.0 \%)$ were uncertain as to whether the attribute rightly defines the nature of the accounting job. With the second attribute, 112(82.9\%) respondents agreed that Accounting involves many rules, regulations and concepts, 3 (2.2\%) disagreed, whiles 18 (13.3\%) were uncertain. Whiles $91(67.4 \%)$ were of the view that CICPA examinations were time consuming and very difficult, with $11(8.2 \%)$ disagreeing to that notion, and 33 $(24.4 \%)$ being uncertain about the notion. Again, in understanding whether CICPA exams is designed for intelligent peoples or not, $49(36.3 \%)$ of the respondents fell under the uncertain category, $43(31.9 \%)$ disagreed that it was designed for smart people, $43(31.9 \%)$ agreed that its design connoted the category of people it was considering (intelligent). The cost of becoming a CICPA is highly believed to be costly. With 61 (45.2\%) respondents agreeing that becoming a CICPA involves a lot of cost, $38(28.1 \%)$ disagreed, and $36(26.7 \%)$ were uncertain, In terms of requirements, 102 (75.6\%) agreed that CICPA requires high entry requirements, $21(15.6 \%)$ were uncertain of their stance, but $12(8.9 \%)$ disagreed.

Table 5: Public and Private Accounting job choice

\begin{tabular}{|c|c|c|c|c|c|}
\hline Variables & $\begin{array}{l}\text { strongly } \\
\text { Disagree }\end{array}$ & Disagree & Uncertain & Agree & $\begin{array}{l}\text { Strongly } \\
\text { Agree }\end{array}$ \\
\hline $\begin{array}{l}\text { Public accounting jobs offer better } \\
\text { pension plan than Private Accounting } \\
\text { jobs. }\end{array}$ & $4(3.0)$ & $15(11.1)$ & $53(39.3)$ & $53(39.3)$ & $9(6.7)$ \\
\hline $\begin{array}{l}\text { Public accounting jobs offer high salary } \\
\text { than private accounting jobs }\end{array}$ & $7(5.2)$ & $50(37.0)$ & $54(40.0)$ & $21(15.6)$ & $2(1.5)$ \\
\hline $\begin{array}{l}\text { A public accounting job offers } \\
\text { opportunities for training and } \\
\text { development than private accounting } \\
\text { jobs. }\end{array}$ & $7(5.2)$ & $51(37.8)$ & $52(38.5)$ & $23(17.0)$ & $2(1.5)$ \\
\hline $\begin{array}{l}\text { Public accounting job have flexible } \\
\text { working environment than private } \\
\text { accounting jobs. }\end{array}$ & $2(1.5)$ & $32(23.7)$ & $53(39.3)$ & $42(31.1)$ & $6(4.4)$ \\
\hline $\begin{array}{l}\text { Public accounting job have good terms } \\
\text { of service than private accounting jobs } \\
\text { Public accounting job have more }\end{array}$ & $1(0.7)$ & $9(6.7)$ & $22(16.3)$ & $80(59.3)$ & $23(17.0)$ \\
\hline vacancies than private accounting jobs & $6(4.4)$ & $39(28.9)$ & $58(43.0)$ & $22(16.3)$ & $10(7.4)$ \\
\hline $\begin{array}{l}\text { Public accounting jobs have better } \\
\text { opportunities for socialization than } \\
\text { private accounting jobs }\end{array}$ & $1(0.7)$ & $26(19.3)$ & $51(37.8)$ & $45(33.3)$ & $12(8.9)$ \\
\hline $\begin{array}{l}\text { Public accounting job are more ruled } \\
\text { based than private accounting jobs }\end{array}$ & $2(1.5)$ & $17(12.6)$ & $42(31.1)$ & $54(40.0)$ & $20(14.8)$ \\
\hline $\begin{array}{l}\text { I prefer working as a public auditor to } \\
\text { private auditor }\end{array}$ & $12(8.9)$ & $36(26.7)$ & $52(38.5)$ & $26(19.3)$ & $9(6.7)$ \\
\hline $\begin{array}{l}\text { I prefer working as a public accountant } \\
\text { to private accountant }\end{array}$ & $9(6.7)$ & $40(29.6)$ & $53(39.3)$ & $24(17.8)$ & $9(6.7)$ \\
\hline
\end{tabular}

Source: Field Data 2018

In the choice of being a private or public Accounting, $62(46.0 \%)$ believed that public Accounting job has a better pension plan than private Accounting, whereas 53 (39.3\%) were equally uncertain, but $19(14.1 \%)$ disagreed. 
In comparison between private and public Accounting in terms of salary offers, a high percentage of $40(29.6 \%)$ were uncertain with which job pays better, $57(42.2 \%)$ disagreed that public accounting job offers high salary than private accounting, $21(15.6 \%)$ agreed that public accounting offers a higher salary than private, but $9(6.7 \%)$ disagreed. Whiles $52(38.5 \%)$ respondents were uncertain as to whether public accounting jobs offers opportunities for training and development than private accounting jobs, $58(43.0 \%)$ disagreed, but was agreed by $25(18.5 \%)$. In the aspect of a flexible working environment, $53(39.3 \%)$ were uncertain whether the private or public Accounting job offers a more flexible working environment, 48 (35.5\%) agreed that public accounting offers a flexible one, $34(24.2 \%)$ disagreed with the notion that the public sector was quite flexible. Also, the question of which job (the private and the public) has good terms of service, $103(76.3 \%)$ agreed that public accounting has good terms of service, $22(16.3 \%)$ were uncertain, leaving $10(7.4 \%)$ disagreeing. And also $104(77.0 \%)$ agreed that public accounting job has a better security assurance than private accounting jobs, $21(15.6 \%)$ were uncertain, and $10(7.4 \%)$ disagreed to that notion.

In the aspect of job vacancies, $58(43 \%)$ were uncertain amongst the two categories (private and public) that had more vacancies, $45(33.3 \%)$ disagreed that the public sector had more vacancies, and $32(23.7 \%)$ agreed that public accounting had more vacancies. Whiles 51 (37.8\%) were uncertain with which sector has the potential for socialization, $57(42.2 \%)$ were positive that the public sector offer the opportunity for socializing than the private sector, and $27(20.0 \%)$ disagreed with such an assertion. Furthermore, 74 (54.8\%) agreed that public accounting jobs are more ruled than private accounting jobs. 42 (31.1\%) were uncertain, $19(14.1 \%)$ opposed that assertion. Also in preference to which sector most of the respondents would work as an Auditor, $52(38.5 \%)$ were uncertain in their choice, $35(26.0 \%)$ preferred the public sector, whereas $48(35.6 \%)$ disagreed to work as an auditor in the public sector. In relation to aspect of preference, $53(39.3 \%)$ were uncertain whether they will opt for private accounting or public accounting jobs. $49(36.3 \%)$ were not ready to choose public accounting over the private, but $33(24.5 \%)$ were ready to render their services to the public sector.

Reliability Test

Reliability refers to a measure of the degree to which research instruments yield consistent results (Mugenda \& Mugenda, 2003). In this study, reliability was ascertained by pre-testing the questionnaire with a selected sample of students from a different programme to avert biasness. The reliability test was done on three factors of the instrument. After data had been collected and entered into Statistical Package for Service Solution (SPSS), Cronbach's Alpha $(\alpha)$ was computed to determine the reliability coefficient.

According to Fraenkel and Wallen (2000), a reliability coefficient of .7 or better is acceptable. In support of this assertion, Abington-Cooper (2005) also emphasized that such a reliability coefficient is good and the instrument can be judged to collect useful data. The Alpha value obtained was .838 ( $\mathrm{n}$ of items $=30$ ), and therefore the instrument was judged to be reliable and acceptable for collecting useful data for the study. No item was deleted or changed on the questionnaire. In order to determine the reliability for each of the main sub-scales on the questionnaire, Cronbach Alpha was computed for each of the main sub scales. The main sub-scales were negative accountant's attitude, image of the accounting profession, accounting job outcomes, accounting job requirements and public and private accounting job choice. Table 3 shows the reliability coefficients for these subscales on the questionnaire.

Table 6 - Reliability Coefficient for Each of the Sub-Scales on the Questionnaire

\begin{tabular}{ll}
\hline Sub-Scale & Reliability Coefficient $(\boldsymbol{\alpha})$ \\
\hline Negative Accountant's Attitude & $.897(\mathrm{~N}$ of items $=6)$ \\
Image of the Accounting Profession & $.673(\mathrm{~N}$ of items $=4)$ \\
Accounting job outcomes & $.677(\mathrm{~N}$ of items $=3)$ \\
Accounting job requirements & $.764(\mathrm{~N}$ of items $=6)$ \\
Public \& Private Accounting job choice & $.716(\mathrm{~N}$ of items $=11)$ \\
Reliability coefficient for sub-scales & $.838(\mathrm{~N}$ of items $=30)$ \\
\hline
\end{tabular}

Source: Field work, 2019.

Validity

The accuracy of data collected largely depended on the data collection instrument in terms of validity. Validity as noted by Robinson (2002) is the degree to which result obtained from the analysis of the data actually represents the phenomenon under study. Validity was ascertained by having all the objective questions included in the questionnaire.

Both the face validity and content validity was determined by the researcher's supervisors. The questionnaire was judged to be valid in terms of face and content validity. After the actual data has been collected, Cronbach's Alpha was again computed to determine the reliability of the instrument for the actual data collected. The reliability coefficient of $.838(\mathrm{~N}$ of items $=30)$ was obtained for the instrument. 
Table 7: Differences in the masters and Bachelor degree students' perceptions

\begin{tabular}{|c|c|c|c|c|c|c|c|c|c|}
\hline & \multicolumn{3}{|c|}{ Bachelor $(n=43)$} & \multicolumn{3}{|c|}{ Master $(n=92)$} & \multicolumn{3}{|c|}{$\begin{array}{l}\text { Group difference } \\
(\mathrm{df}=1 \text {, alpha at } 0.05)\end{array}$} \\
\hline & mean & Std dv & $\begin{array}{l}\text { Mean } \\
\text { Ranks }\end{array}$ & Mean & Std dv & $\begin{array}{l}\text { Mean } \\
\text { Ranks }\end{array}$ & $\mathrm{H}(\mathrm{x} 2)$ & sign & Remarks \\
\hline $\begin{array}{l}\text { An accountant is } \\
\text { mostly intelligent and } \\
\text { hardworking }\end{array}$ & 3.721 & 1.031 & 64.97 & 3.826 & 0.98 & 69.42 & 0.433 & 0.511 & $\begin{array}{l}\text { no } \\
\text { difference }\end{array}$ \\
\hline $\begin{array}{l}\text { An accountant is } \\
\text { mostly respected and } \\
\text { admired by people }\end{array}$ & 2.953 & 0.899 & 55.79 & 3.413 & 0.985 & 73.71 & 6.796 & $0.009 *$ & Difference \\
\hline $\begin{array}{l}\text { An accountant is } \\
\text { decent and punctual } \\
\text { and is mostly given } \\
\text { societal recognition }\end{array}$ & 3.31 & 0.841 & 60.51 & 3.543 & 0.882 & 70.69 & 2.32 & 0.128 & $\begin{array}{l}\text { no } \\
\text { difference }\end{array}$ \\
\hline $\begin{array}{l}\text { Accounting job is } \\
\text { dull, routinely and } \\
\text { monotonous }\end{array}$ & 3.372 & 0.9 & 66.38 & 3.446 & 0.906 & 68.76 & 0.121 & 0.728 & $\begin{array}{l}\text { no } \\
\text { difference }\end{array}$ \\
\hline
\end{tabular}

In terms of differences in perceptions, according to the results of Kruskal-Wallis $\mathrm{H}$ test there was a statistically significant difference between the perceptions of bachelors and masters students that accountants are mostly respected which recorded a chi square value of 6.796 with a probability of 0.009 , a rank perception rating of 55.79 for bachelor students with sample size of 43 while masters students had a mean rank of 73.71 with a sample size of 93. This implies that master students rated their perception higher than the bachelor students.

Apart from the above, there is no significant difference in the perceptions since they all have $\mathrm{p}$ values higher than the calculated $p$ values. An accountant is mostly intelligent and hardworking has a chi square value of 0.433 with a significant value of 0.511 , An accountant is decent and punctual and is mostly given societal recognition had a chi square value 2.32 with a significant value of 0.128 and Accounting job is dull, routinely and monotonous had a chi square value of 0.121 with a significant value of 0.728 .

Table 8:

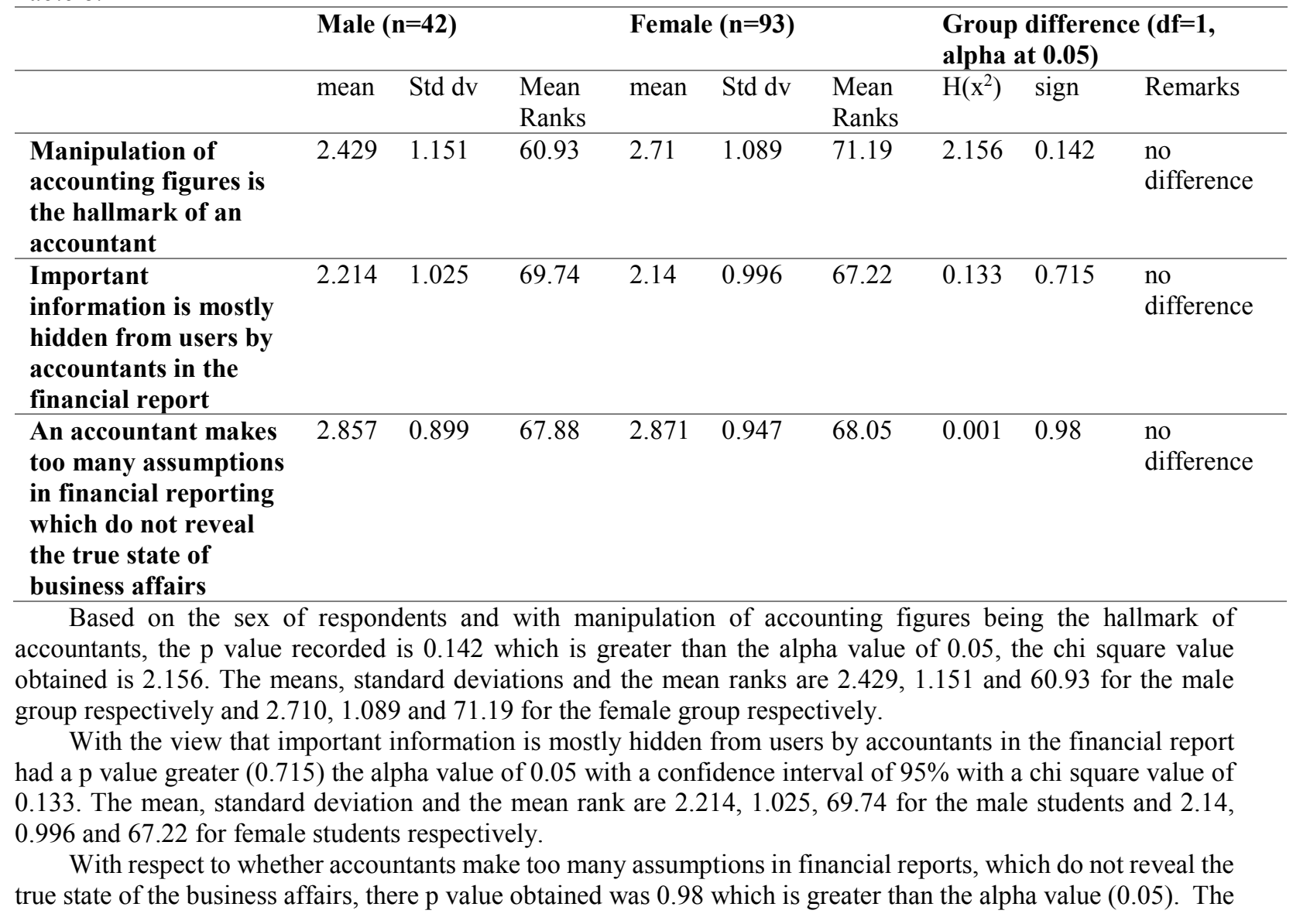


means 2.857 and 2.871, standard deviations 0.899 and 0.947 , mean ranks 67.88 and 68.05 for males and females respectively.

Table 9 describes a summary of the effect of accountant's negative attitude, accounting job requirement, image of the accounting profession and accounting job outcomes on student's choice of public accounting job or accounting job intentions.

Table 9 -Summary of the effect of accountant's negative attitude, accounting job requirement, image of the accounting profession and accounting job outcomes on student's choice of public accounting job or accounting job intentions.

\begin{tabular}{llllll}
\hline & Coefficient & Std. Error & Beta & t-value & Sig. \\
\hline Constant & 4.854 & 5.161 & & 0.941 & 0.349 \\
Accountant's negative attitude & 0.253 & 0.166 & 0.122 & 1.531 & 0.128 \\
Accounting job requirement & 0.415 & 0.222 & 0.169 & 1.864 & 0.065 \\
Image of the Accounting Profession & 0.245 & 0.363 & 0.066 & 0.673 & 0.502 \\
Accounting job outcomes & 1.421 & 0.499 & 0.288 & 2.846 & 0.005 \\
\hline
\end{tabular}

Source: Field Data 2019; R-Sq. $=0.234, p=0.05$

A multiple regression was conducted to determine the effect of accountant's negative attitude, accounting job requirement, image of the accounting profession and accounting job outcomes on student's choice of public accounting job or job intentions (dependent variable).

From table 9, the estimated multiple regression equation is given as

$\mathrm{Y}=4.854+0.253 X_{1}+0.415 X_{2}+0.245 X_{3}+1.421 X_{4}$

Where $\mathrm{Y}=$ Students' choice of Public accounting job or job intention

$$
\begin{aligned}
& X_{1}=\text { Accountant's negative attitude } \\
& X_{2}=\text { Accounting job requirement } \\
& X_{3}=\text { Image of the accounting profession } \\
& X_{4}=\text { Accounting job outcomes }
\end{aligned}
$$

The results from table 9 showed that only $23.4 \%$ of the variations in students' choice of public accounting job is caused by changes in the independent variables. Thus, $23.4 \%$ of the changes in students' choice of public accounting job can be attributed to accountant's negative attitude, accounting job requirement, image of the accounting profession and accounting job outcomes. The estimated regression line indicates that a $1 \%$ increase in Accountant's negative attitude, accounting job requirement, image of the accounting profession and accounting job outcomes will lead to $0.253,0.415,0.245$ and 1.421 respectively increase in students' choice of public accounting job. The coefficient of accountant's negative attitude, accounting job requirement and image of the accounting profession were statistically insignificant since their p-values, $0.128,0.065$ and 0.502 are greater than (0.05) significance level. But the coefficient of the accounting job outcome was statistically significant since its $\mathrm{p}$ value $(0.005)$ is less than (0.05) significance level. Hence there is a positive relationship between accounting job outcome and students' job intention. This conform the findings of Karakaya, Quigley and Bingham (2011). Their findings indicated that individuals' choice of careers is determined by the perceived outcomes (benefits) of the job.

\section{Findings}

From the data, a t test was conducted and also the $\mathrm{p}$ values were calculated using gender as a dependent variable. Based on accountant's perception, the $\mathrm{p}$ values were higher than the alpha value used. Hence we fail to reject the claim at a confidence interval of $95 \%$ since the calculated $p$ values are greater than the alpha value used $(0.05)$. The various $p$ values for the various determinants are Manipulation of accounting figures is the hallmark of an accountant (0.105), important information is mostly hidden from users by accountants in the financial report $(0.336)$ and an accountant makes too many assumptions in financial reporting which do not reveal the true state of business affairs (0.984)

$P$ values calculated are An accountant is mostly intelligent and hardworking (0.446), An accountant is mostly respected and admired by people (0.016), An accountant is decent and punctual and is mostly given societal recognition (0.723) and Accounting job is dull, routinely and monotonous (0.767), the $\mathrm{P}$ values are greater than 0.05 which means that we cannot reject the claim. In relation to accountant is mostly respected and admire by people, the $\mathrm{p}$ value is 00.016 which is less than the alpha value used hence rejected.

There is a negative relationship between accounting tertiary students perception. The perceptions of accounting jobs and career choice are tested if it is true. From the analysis, The variables for the perceptions have $\mathrm{p}$ values higher than 0.05 , which means that there is a no difference between tertiary students perception and career choice except for career choice that states that it costs a lot for one to become CICPA which have a probability less than 0.05 and CICPA exams are time consuming and difficult with a calculated probability of 0.01 .

The difference between undergraduate and graduate accounting student's perception of accounting jobs demand which will cause one to work in the private of public firm is also tested. All other factors tested hold except some few which state that public accounting jobs are more ruled based than private accounting jobs with a 
probability of 0.02 which is less than 0.05 . Majority of the students prefer working with private firms to public firms.

The effect of accountant's negative attitude, accounting job requirement, image of the accounting profession and accounting job outcomes on student's choice of public accounting job were tested. The results indicated that the coefficients of accountant's negative attitude accounting job requirement and image of the accounting profession were statistically insignificant. But the coefficient of the accounting job outcome was statistically significant since its p-value (0.005) is less than (0.05) significance level. Hence, a $1 \%$ increase in accounting job outcome will lead to 1.421 increases in students' job intention in public accounting job. This conform the findings of Karakaya, Quigley and Bingham (2011). Their findings indicated that individuals' choice of careers is determined by the perceived outcomes (benefits) of the job.

\section{CONCLUSIONS AND RECOMMENDATIONS}

This chapter presents the summary of the data that was collected for the study. It also summarizes the major findings and presents the conclusions that were drawn from the study. The chapter further outlines the recommendations that are made by the researchers on the basis of the findings.

\subsection{Summary, Conclusion and Recommendations}

The purpose of the study was categorized into two folds, firstly, to investigate the perception that accounting students have over the accounting profession, and student's accounting job choice as to either work in public or private sector. The sample in the study were Chinese accounting students in Hangzhou Dianzi University, and these participants were put into two groups as undergraduate and graduate Chinese accounting students. The graduate accounting students included those preparing to attain CPA qualification and the undergraduate were those studying to attain bachelor's degree. The results of the study was very fascinating, it showed that majority of the respondents were against the view that there still exist the negative perceptions of the AP but quite a greater number of the respondents also vehemently rated the profession unfavorably. The question is if accounting students have unfavorable perception over their AP, then how can the AP attract people to it? This shows that AP in China is quite unattractive and Policy Makers must find strategies to solve this unsavory image of the AP in China. The finding affirms the work of (Albrecht, S.W. \& Sack, R. J., 2001; Cory, 1992) provided examples of how accountants were portrayed in the media, arguing that these stereotypes were often used in making career decisions and negative perceptions resulted in a self-fulfilling prophecy. And also the ACCA in their report 'closing value gap 2012 ' find $25 \%$ trust discrepancy in terms of how the profession perceives itself and how the public perceives it.

Although, the Chinese CPA is domestically designed to suite the accounting system and also meet the needs of its firms, my study revealed that there are some challenges that the profession have to put plans in place to eradicate them. The study revealed that CICPA will face shortage of candidates hence a reduction in the number of accountants. This is due to the fact that the profession does not provide a uniform ground for accounting students to partake. Negative or positive perceptions about AP can affect accounting students' intentions (Chia et al., 2008; Dalci et al., 2013; Karakaya et al., 2011), and of joining the profession or being committed to the rigour and demands of the education and training leading to certification in the profession. Most of the respondents agreed that the profession takes too much time, it targets a particular groups of people, and too costly to attain such profession. Satoshi, S., \& Gregory, B. (2007), in their study of the role of perceptions toward the accounting profession by Japanese tertiary business students in the process of career choice also find that; cost, high entry qualification were rate higher by accounting students as a barrier to the AP. On the image of the AP, the study found that accounting job was rated higher by the respondents with regards to the attribute of accounting job being dull, routine and monotonous. Saemann \& Crooker (1999) employed additional t-test analysis which revealed that students who were interested in an accounting career didn't care about the typical image of the profession, but tended to be less creative people. In this regard, the profession will lose more creative people, and also people will forgo these attributes if the benefit outweighs the attributes.

The findings of the study indicated that that individuals' choice of careers is determined by the perceived outcomes (benefits) of the job. This was in sync with the findings of Karakaya, Quigley and Bingham (2011).

Warrick, Daniels and Scott (2010) sounded that in prior research, government accounting (public sector accounting) has a lower perceived value than the practice of accounting in accounting consultancy firms and business organizations. They also found that students prefer the practice of accounting in accounting consultancy firms and business organizations more than working with the government. In considering whether to take public or private accounting jobs by accounting students, the study revealed that Chinese accounting students would like to work in the public sector because it offers better pension plan, flexible working environment, good terms of service, but in totality, to work as a public accountant was found to be least choice by Chinese accounting tertiary students. Obata (2006) argued that the relatively lower level of remuneration paid to Certified Public Accountants in Japan was of major concern, and concluded that this lower economic benefit may discourage students from 
becoming a Certified Public Accountants even though sufficient job security with a governmental certified license has usually been very attractive to students. Most of these Chinese students prefer to work in the private accounting firms than public accounting firms because public accounting jobs are not attractive in terms of its salary offer, that there is no opportunity for training and development, and its lack of job vacancies. Ahmed, K., Alam, K. F., \& Alam, M. (1997) their results show that the students who intend to pursue a CPA career place significantly greater importance on financial and job-related factors and perceived benefit-cost ratio. The results again indicates that good terms of service and better pension plan are the most influential attributes that could lure Chinese accounting student to work in the public accounting jobs China but it's very unfortunate that there are few vacancies in this area. Again, in relation to job choices as to whether to work in the public or private accounting sector, majority of the respondent selected private sector over the public sector. Policy Makers must help make the public job attractive by educating the people about the importance of being a public servant.

This study is the first one that has been conducted to investigate accounting tertiary student's job choice as to either to take up public or private accounting job. This study have brought out the most importunate issues that accounting students face in their job decisions in China. In this regard, the findings would contribute to accounting literature. Despite these hot issues that came out from the study, the study still has limitations. The first limitation was that, the study considered only students majoring in accounting and no other fields such as finance, commerce, and management. Again, the study considered only accounting related jobs and not non-accounting related jobs. It's obvious that, despite these limitations the study would still be helpful to policy makers to make new and modify their strategies in light of the issues identified.

\section{References}

Deci, E. L., Vallerand, R. J., Pelletier, L. G., \& Ryan, R. M. (1991). Motivation and education: The selfdetermination perspective. Educational psychologist, 26(3-4), 325-346.

Corsini, R. J. (2002). The dictionary of psychology. Psychology Press. p. 219. ISBN 978-1-58391-328-4. Retrieved 24 March 2011.

Gaulin, S. J. C. \& McBurney, D. H. (2003) Evolutionary Psychology. Prentice Hall. ISBN 978-0-13-111529-3, Chapter 4, pp. 81-101.

Farb, N., Daubenmier J., Price C. J., Gard T., Kerr C., Dunn B. D., \& Mehling W. E. (2015). "Interoception, contemplative practice, and health". Frontiers in Psychology. 6: 763.

Alan, S. \& Gary, J. (2011). Perception, Attribution, and Judgment of Others. Organizational Behaviour: Understanding and Managing Life at Work Vol. 7

Bruner, J. S., \& Postman, L. (1949). On the perception of incongruity: A paradigm. Journal of personality, 18(2), 206-223

Senarath Yapa, P. W., \& Ping Hao, Z. (2007). An analysis of current trends in accounting professional development in People's Republic of China. Asian Review of Accounting, 15(1), 25-44.

Rivera, I. N., Chun, J., Huq, A., Sack, R. B., \& Colwell, R. R. (2001). Genotypes associated with virulence in environmental isolates of Vibrio cholerae. Applied and Environmental Microbiology, 67(6), 2421-2429.

Karakaya, F., Quigley, C., \& Bingham, F. (2011). A cross-national investigation of student intentions to pursue a sales career. Journal of Marketing Education, 33(1), 18-27.

Cohen, J., \& Hanno, D. M. (1993). An analysis of underlying constructs affecting the choice of accounting as a major. Issues in accounting Education, 8(2), 219.

Cory, S. N. (1992). Quality and quantity of accounting students and the stereotypical accountant: Is there a relationship? Journal of Accounting Education, 10 (Spring), 1-24.

Geiger, M. A. \& Ogilby, S. M. (2000). The first course in accounting: Students' perceptions and their effect on the decision to major in accounting. Journal of Accounting Education, 18 (Spring), 63-78.

Meredith, J. R., Steward, M. D., \& Lewis, B. R. (2011). Knowledge dissemination in operations management: Published perceptions versus academic reality. Omega, 39(4), 435-446.

Saemann, G. P. \& Crooker, K. J. (1999). Student perceptions of the profession and its effect on decisions to major in accounting. Journal of Accounting Education, 17(1), 1-22.

Churchman, R. J. (2013). Attracting the Best and Brightest: An Examination of the Factors That Influence Students Intent to Enter the Accounting Profession.(Unpublished doctoral dissertation).Anderson University, Boulevard, Anderson, South Carolina.

Cameron, R.R. (2010). Ajzen's theory of planned behaviour applied to the use of social networking by college students. Unpublished dissertation, Texas State University-San Marcos.

Krzeski, E. (2011). Using the theory of planned behaviour to understand drink choices in Southwest Virginians. (Unpublished dissertation).State University, Blacksburg, VA, United States.

Vallerand, R.J., Pelletier, L.G., Deshaies, P., Cuerrier, J-P., \& Mongeau, C. (1992). Journal of Personality and Social Psychology, 62(1), 98-109.

Ajzen, I. (1985). From intentions to action: A theory of planned behavior. InJ. Kuhl \& J. Beckman (Eds.) From 
cognition to behaviour, Heidelberg: Springer, 11-39.

Ajzen, I. (1991). The theory of planned behaviour. Organization Behaviour and Human Decision Processes, 50, $179-211$

Ajzen, I. (2005). Attitudes, personality, and behaviour. (2 ${ }^{\text {nd }}$ ed.). New York: McGraw-Hill Education.

Ferreira, A., \& Santoso, A. (2008). Do students' perceptions matter? A study of the effect of students' perceptions on academic performance. Accounting and Finance, 48(209-231). http://dx.doi.org/10.1111/j.1467-629X. 2007.00239.x

Wessels, P. L., \& Steenkamp, L. P. (2009). An investigation into students' perceptions of accountants. Meditari Accountancy Research, 17(1), 117-132. http://dx.doi.org/10.1108/10222529200900008

Solomon, J. F., Solomon, A., Joseph, N. L., \& Norton, S. D. (2013). Impression management, myth creation and fabrication in private social and environmental reporting: Insights from Erving Goffman. Accounting, organizations and society, 38(3), 195-213.

Germanou, E., Hassall, T., \& Tournas, Y. (2009). Students' perceptions of accounting profession: Work value approach. Asian Review of Accounting, 17(2), 136-148. http://dx.doi.org/10.1108/13217340910975279

Góis, C. G., \& Brás, F. A. (2013). In the aftermath of the Bologna process: Exploring the master students perceptions on accounting in two Portuguese higher education institutions. Educade: revista de educación encontabilidad, finanzas y administración de empresas, 4, 34-55.

The ACCA, Ghana, (2005). Report on Qualified Accountants in Ghana. Retrieved from http://www.ghanaweb.com/GhanaHomePage/business/artikel.php?ID=87965

Chen, C., Jones, K.T., \& Mclntyre, D. (2005). A reexamination of the factors important to selection of Accounting as a major. Accounting and the Public Interest, 5, 14-31.

Nwobu, O., Faboyede, O. S., \& Oyewo, B (2015). Accounting students' choice to pursue a career in the industry or academics: Lesson from selected private Nigerian universities. In ICERI Conference Proceedings.

Ahmed, K., Alam, K. F., \& Alam, M. (1997). An empirical study of factors affecting accounting student's career choice in New Zealand. Accounting Education, 6(4), 325-335.

Kloo D., Perner, J., \& Gritzer, T. (2010). Object-based set-shifting in preschoolers: Relations to Theory of Mind.

Mbawuni, J. (2015). Examining students' feelings and perceptions of accounting profession in a developing country: The role of gender and student category. International Education Studies, 8(6), 9.

CICPA (2016), overview of the Accountancy Profession in China, http://www.cicpa.org.cn

Satoshi, S., \& Gregory, B. (2007). The role of perceptions toward the accounting profession by Japanese tertiary business students in the process of career choice.

Armitage, C. J., \& Conner, M. (2001). Efficacy of the theory of planned behaviour: A meta - analytic review. British journal of social psychology, 40(4), 471-499.

Sugahara, S., \& Gregory, B., (2006). Perceptions of the certified public accountants by accounting and nonaccounting tertiary students in Japan. Asian Review of Accounting, 14(1/2), 149-167.

Hair, J. F., Black, W. C., Babin, B. J., \& Anderson, R. E. (2010). Multivariate Data Analysis. Englewood Cliffs, NJ: Prentice Hall.

Fisher, R., \& Murphy, V. (1995). A pariah profession? Some student perceptions of accounting and accountancy. Studies in Higher Education, 20(1), 45-58.

Friedlan, J. M. (1995). The effects of different teaching approaches on students' perceptions of the skills needed for success in accounting courses and by practicing accountants. Issues in Accounting Education, $10(1), 47$.

Saudagaran, S. M. (1996). The first course in accounting: An innovative approach. Issues in Accounting Education, $11(1), 83$.

Mladenovic, R. (2000). An investigation into ways of challenging introductory accounting students' negative perceptions of accounting. Accounting Education, 9(2), 135-155.

Byrne, M., \& Willis, P. (2005). Irish secondary students' perceptions of the work of an accountant and the accounting profession. Accounting Education: an international journal, 14(4), 367-381.

Arthur, M. B., Khapova, S. N., \& Wilderom, C. P. (2005). Career success in a boundaryless career world. Journal of Organizational Behavior: The International Journal of Industrial, Occupational and Organizational Psychology and Behavior, 26(2), 177-202.

Marriott, P. R. U., \& Marriott, N. (2003). Are we turning them on? A longitudinal study of undergraduate accounting students' attitudes towards accounting as a profession. Accounting education, 12(2), 113-133.

Association of Chartered Certified Accountants (ACCA). (2012). Closing the value gap report. The accountant (3 September 2012 by Jared Fortune).

Demagalhaes, R., Wilde, H., \& Fitzgerald, L. R. (2011). Factors affecting accounting students' employment choices: a comparison of students' and practitioners' views. Journal of Higher Education Theory and Practice, 11(2), 32-41.

Fishbein, M., \& Ajzen, I. (1975). Belief, attitude, intention and behavior: An introduction to theory and research. White, G. M. (2003). Identity through history: Living stories in a Solomon Islands society (Vol. 83). Cambridge 
University Press.

Senarath Yapa, P. W., \& Ping Hao, Z. (2007). An analysis of current trends in accounting professional development in People's Republic of China. Asian Review of Accounting, 15(1), 25-44.

Rivera, G., Elliott, S., Caldas, L. S., Nicolossi, G., Coradin, V. T., \& Borchert, R. (2002). Increasing day-length induces spring flushing of tropical dry forest trees in the absence of rain. Trees, 16(7), 445-456.

Obata, N. (2006). White noise calculus and Fock space. Springer.

Warrick, C. S., Daniels, B., \& Scott, C. (2010). Accounting students' perceptions on employment opportunities. Research in Higher Education Journal, 7, 1.

Fiske, S. T., \& Taylor, S. E. (2013). Social cognition: From brains to culture. Sage.

Mugenda, O. M., \& Mugenda, A. G. (2003). Research methods: Quantitative and qualitative approaches. Nairobi: ACTS Press.

Robinson, S. (2002). Research methodology. Washington, DC: National Academies Press.

Fraenkel, J., \& Wallen, N. (2000). How to design and evaluate research in education (4th ed.). New York: McGraw-Hill, Inc.

Abington-Cooper, M. (2005). An evaluation of the LSU Agricultural Center's agricultural leadership development program, 1988-2004 (Doctoral dissertation, Northeast Louisiana University). 